\title{
Effect of Using Slow-Release Urea on Milk Production and its Composition of Lactating Dairy Cows
}

\author{
E. M. Abdel-Raouf, M. I. Bassiouni, M. F. Ali and H. E. Hassanien \\ Department of Animal Production, Faculty of Agriculture, Kafrelsheikh University, \\ Kafrelsheikh, Egypt.
}

\begin{abstract}
$\mathbf{T}$ WELVE lactating Holstein cows with live body weight from 550 to $680 \mathrm{~kg}$ averaging 600 $\pm 15 \mathrm{~kg}$ and at $1-4$ of lactation seasons were used in Latin square design $(3 \times 3)$ with three treatments and three successive experimental periods. Cows in G1 were fed the basal ration consisted of (on DM basis) $57.7 \%$ concentrate feed mixture (CFM) $+24.7 \%$ corn silage (CS) $+17.6 \%$ alfalfa hay (AH) without supplementation and served as a control. While, in G2 and G3, 1 and $0.5 \mathrm{~kg}$ soybean meal was replaced by 125 and $62.5 \mathrm{~g}$ Optigen $^{\mathrm{TM}}$ plus 2.710 and $1.355 \mathrm{~kg}$ corn silage/ head/ day, respectively. Results showed that the contents of DM, OM, $\mathrm{CP}, \mathrm{NFC}$ and NFE in experimental rations tended to decrease, however, the contents of CF, $\mathrm{NDF}, \mathrm{ADF}$ and ash tended to increase with increasing the level of Optigen supplementation. The digestibility coefficients of all nutrients and nutritive values were not significantly affected by Optigen supplementation. Average daily intake of total DM, TDN, CP, DCP, DE, ME and NEL were nearly similar for the different experimental rations. Moreover, average daily yield of actual milk and 4\% FCM, milk composition, the concentrations of urea and urea-N in milk, the concentrations of urea-N and total protein in blood plasma, feed conversion ratio, daily feed cost, feed cost $/ \mathrm{kg}$ milk and economic efficiency were not affected significantly $(\mathrm{P}>0.05)$ by Optigen supplementation. It could be concluded that optigen supplementation for lactating Holstein cows did not showed any significant effects on feed intake, digestibility, milk yield and composition along with feed conversion ratio and economic efficiency.
\end{abstract}

Keywords : Lactating Holstein cows, Optigen, Digestibility, Milk yield, Composition.

\section{Introduction}

Optigen ${ }^{\circledR} \quad$ (Alltech, Nicholasville, KY) is a feed additive product containing $256 \%$ CP for cattle that combines a urea coated in a biodegradable polymer and fibrolytic enzyme technology (Krehbiel et al., 2007). The limited

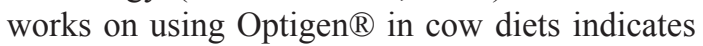
that Optigen ${ }^{\circledR}$ is a suitable partial replacement of an oilseed meal for forage fed cattle. A novel characteristic of Optigen ${ }^{\circledR}$ is the unique combination of the coated urea with a fibrolytic feed enzyme (FFE) in the form of xylanase (minimum $40 \mathrm{Xu} \mathrm{XU} \bullet \mathrm{g}-1$ ). The addition of fibrolytic feed enzymes in the diet improves fiber digestion, often resulting in increased passage rate (Murillo et al., 2000 and Beauchemin et al.,
2004). Optigen ${ }^{\circledR}$ (Alltech, Inc., Nicholasville, $\mathrm{KY}$ ), which is the trade name for the slow-release NPN product in Optigen $\AA$. Optigen $\AA$ is urea coated in a biodegradable polymer, which causes controlled release of the urea (Akay et al., 2004 and García-González et al., 2007). Optigen rII (Alltech Inc.) is a blended, controlled release urea source. Urea is coated in a polyester polyurethane coating which allows the diffusion of the urea through micro-pores, that slows down the rate of nitrogen release in the rumen (ICF Consulting, 2004). The idea of Optigen rII is to give a slow even release of nitrogen over 24 hours, to meet the rumen bacteria requirements when rumen NH3-N levels are low. To provide a sustained level of $\mathrm{N}$, $\mathrm{N}$ efficiency and microbial protein production would increase (Harrison and Karnezos, 2005). 
Inclusion of Optigen ${ }^{\circledR}$ in cow supplements often results in no reduction in cow performance, blood metabolites, or milk yield, indicating that it successfully replaces other sources of protein in the diet (Akay et al., 2004). Inclusion of

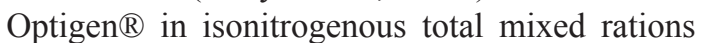
(TMR) also has no impact on milk yield (Galo et al. 2003 and Dos Santos et al., 2008). Tedeschi et al. (2002) fed a polymer-coated slow release urea (Optigen 1200) and found an improvement in feed efficiency. Holder (2012) found that high degradable intake protein (DIP) level in the diet of cattle improved feed efficiency.

The objective of this study was to investigate the effect of Optigen supplementation in the ration of dairy Holstein Friesian cows on feed intake, digestibility, blood plasma total protein and urea nitrogen, milk yield and composition, feed conversion ratio and economic efficiency.

\section{Materials and Methods}

\section{Experimental animals and rations}

Twelve lactating Holstein cows with live body weight from 550 to $680 \mathrm{~kg}$ averaging $600 \pm 15 \mathrm{~kg}$, and at 1-4 of lactation seasons were used after 6 weeks of lactation in Latin square design $(3 \times 3)$ with three treatments (4 cows in each) and three successive experimental periods (4 weeks each). Cows in 1st group were fed the basal ration consisted of (on DM basis) 57.7\% concentrate feed mixture (CFM) $+24.7 \%$ corn silage $(\mathrm{CS})+17.6 \%$ alfalfa hay $(\mathrm{AH})$ without supplementation and served as a control (G1). While, in $2^{\text {nd }}$ and $3 \mathrm{rd}$ groups, 1 and $0.5 \mathrm{~kg}$ soybean meal were replaced by 125 and 62.5 g Optigen $^{\mathrm{TM}}$ plus 2.710 and $1.355 \mathrm{~kg}$ corn silage/head/day for G2 and G3, respectively. Chemical analyses of experimental rations were carried out to determine DM, CP, CF, EE, ash according to the methods of AOAC (2000). Neutral detergent fiber (NDF) was determined according to Van Soest and Marcus (1964). Acid detergent fiber (ADF) and acid detergent lignin (ADL) were determined according to Van Soest (1963). Hemicellulose $=\mathrm{NDF}-\mathrm{ADF}$ and Cellulose $=\mathrm{ADF}-\mathrm{ADL}$. Where non fiber carbohydrates $(\mathrm{NFC})=100-$ (NDF+CP+Fat+Ash) according to Hall (2003). The formulation of the different experimental rations shows in Table 1.

\section{Management procedure}

Cows were housed in open yard with a shed area about one third of the total space area. Cows were received a diet to meet maintenance, growth and lactation requirements and classified into groups according to days in milk (DIM), milk yield, parity and body condition score. Cows were fed their rations ad libtum computed according to recommendations of the NRC (2001) and the daily intake of feedstuffs was recorded individually for each cow. The rations introduced 3 times daily over 20 hours a day. Clean, ample water was available for animals all the day round.

\section{Digestibility trial}

Digestibility trial was conducted during experimental period using all cows to determine nutrients digestibility coefficients and nutritive values of the experimental rations. Samples of feedstuffs were taken at the beginning, middle and end of collection period. Feces samples were taken from the rectum of each cow twice daily with $12 \mathrm{hr}$ interval during the collection period. Samples of feedstuffs and feces were composited and dried in a forced air oven at $65^{\circ} \mathrm{C}$ for $48 \mathrm{hr}$ and ground. Chemical analysis of samples of feedstuffs and feces were carried out to determine $\mathrm{DM}, \mathrm{CP}, \mathrm{CF}, \mathrm{EE}$, ash according to the methods of AOAC (2000). Acid insoluble ash (AIA) was used as a natural marker as described by Van Keulen and Young (1977). Nutrients digestibility was calculated from the equations stated by Schneider and Flatt (1975).

DM digestibility $\%=100-\left[100 \times \frac{\text { AIA } \% \text { in feed }}{\text { AIA } \% \text { in feces }}\right]$

Nutrient digestibility $\%=$

$$
100-\left\lceil 100 \times \frac{\text { AIA } \% \text { in feed }}{\text { AIA } \% \text { in feces }}\right\rceil \times\left[\frac{\text { Nutrient } \% \text { in feces }}{\text { Nutrient } \% \text { in feed }}\right\rceil
$$

Energy values were calculated according to the equations of NRC (2001) as follows :

$1-\mathrm{DE}(\mathrm{Mcal} / \mathrm{kg})=\mathrm{TDN}(\%) \times 0.04409$

$2-\mathrm{ME}(\mathrm{Mcal} / \mathrm{kg})=1.01 \times \mathrm{DE}(\mathrm{Mcal} / \mathrm{kg})-0.45$

$3-\mathrm{NEl}(\mathrm{Mcal} / \mathrm{kg})=0.0245 \times \mathrm{TDN}(\%)-0.12$

\section{Milk yield and samples}

Cows were mechanically milked three times daily (5:00 am, 1:00 pm and 9:00 pm) and the average milk yield per cow, per day, per week, per month and per lactation season was recorded automatically (Afikim- herd management system). Milk samples were taken at the $4^{\text {th }}$ week for each period from the three milking times and composited 
for each cow in proportion to milk yield. Milk samples mixed well for analysis of fat, protein, lactose. Solid not fat (SNF), total solids (TS) and urea nitrogen by the infrared spectrophotometry (Foss 120 Milko Scan, Foss Electric, Hillered, Denmark). The $4 \%$ fat corrected milk (FCM) for each cow was calculated from milk yield according to the following formula :

$4 \% \mathrm{FCM}=$ Actual milk yield $(\mathrm{kg}) \times 0.4$

$+15 \mathrm{x}$ fat yield $(\mathrm{kg})$ (Gaines, 1928).

TABLE 1. Formulation of experimental rations (\%, on DM basis) and prices of feedstuffs used in feeding dairy cows in different treatments.

\begin{tabular}{|c|c|c|c|c|}
\hline \multirow{2}{*}{ Feedstuffs } & \multicolumn{3}{|c|}{ Treatments } & \multirow{2}{*}{ Price* (LE/kg) } \\
\hline & G1 & G2 & G3 & \\
\hline Corn grain ground & 22.38 & 22.38 & 22.38 & 2.20 \\
\hline Linseed meal & 3.86 & 3.86 & 3.86 & 4.50 \\
\hline Wheat bran & 1.89 & 1.89 & 1.89 & 1.80 \\
\hline Rice bran & 5.79 & 5.79 & 5.79 & 2.20 \\
\hline Soya bean meal $47 \%$ & 15.10 & 11.32 & 13.20 & 5.00 \\
\hline Sugar beet bulb dried & 4.24 & 4.24 & 4.24 & 1.50 \\
\hline Alfalfa hay $18 \% \mathrm{CP}$ & 17.17 & 17.17 & 17.17 & 1.70 \\
\hline Corn silage & 26.11 & 29.36 & 27.75 & 0.45 \\
\hline Calcium soap of fatty acid $84 \%$ (Megalac $\left.{ }^{\mathrm{TM}}\right)$ & 2.10 & 2.10 & 2.10 & 6.50 \\
\hline Protected methionine (Meprone ${ }^{\mathrm{TM}}$ ) & 0.04 & 0.04 & 0.04 & 12.00 \\
\hline Mono-calcium phosphate & 0.08 & 0.08 & 0.08 & 6.50 \\
\hline Limestone & 0.20 & 0.20 & 0.20 & 0.20 \\
\hline Magnesium oxide $80 \%$ & 0.17 & 0.17 & 0.17 & 3.00 \\
\hline Sodium bicarbonate & 0.20 & 0.20 & 0.20 & 3.20 \\
\hline Common salt & 0.33 & 0.33 & 0.33 & 0.45 \\
\hline Mineral mix $\left(\text { Multimix }{ }^{\mathrm{TM}}\right)^{* *}$ & 0.19 & 0.19 & 0.19 & 5.50 \\
\hline Vitamin mix $(\mathrm{AD} 3 \mathrm{E}) * * *$ & 0.10 & 0.10 & 0.10 & 17.00 \\
\hline Chelated mineral (Avila4 ${ }^{\mathrm{TM}}$ ) $* * * *$ & 0.03 & 0.03 & 0.03 & 45.00 \\
\hline Mycotoxin binder (Capt2 $\left.{ }^{\mathrm{TM}}\right)$ & 0.02 & 0.02 & 0.02 & 120.00 \\
\hline Slow release urea (Optigen $1200^{\mathrm{TM}}$ ) & 0.00 & 0.53 & 0.26 & 20.00 \\
\hline Total & 100.00 & 100.00 & 100.00 & \\
\hline Concentrate: Roughage ratio & $56.7: 43.2$ & $53.4: 46.5$ & $55.0: 44.9$ & \\
\hline
\end{tabular}

* According to prices of 2015.

** Minerals mix: Each 2 Kg of Mixture Contains: Zinc 100,000 mg, Manganese 80,000 mg, Copper 30,000 mg, Iodine $800 \mathrm{mg}$, Cobalt $400 \mathrm{mg}$, Selenium $300 \mathrm{mg}$ and Carrier (Ca Co3) up to $2 \mathrm{~kg}$.

*** Vitamins mix: Each $1 \mathrm{Kg}$ of Mixture Contains: Vitamin A 9000,000 IU, Vitamin D 2500,000 IU, Vitamin E 35,000 $\mathrm{mg}$ and Carrier $(\mathrm{Ca} \mathrm{Co} 3)$ up to $1 \mathrm{~kg}$.

**** Chelated mineral (Avila4TM): Zinc chelated of Methionine 26.5\%, Manganese chelated of Methionine 17.5\%, Copper chelated of Methionine $9.2 \%$ and Cobalt chelated of Methionine 2.5\% and Carrier: calcium carbonate $8.9 \%$ and Ground corn cob 35.4\%, analysis: Zinc 5.15\%, Manganese 2.86\%, Copper $1.80 \%$ and Cobalt $0.18 \%$.

\section{Blood samples}

Blood samples were collected at the $4^{\text {th }}$ week of each period in heparinized clean test tubes via the jugular vein from all cows in each group. Samples were centrifuged at 4000 r.p.m. for 10 min to obtain plasma. Concentrations of total protein and urea nitrogen in blood plasma were determined using commercial kits (Diagnostic System Laboratories, Inc USA).

\section{Feed conversion ratio}

Feed conversion ratio expressed as the amounts of DM, TDN, DE, ME, NEl and DCP required per one $\mathrm{kg} 4 \% \mathrm{FCM}$ yield were calculated for each cow. 


\section{Economic efficiency}

Average daily feed cost, feed cost per one $\mathrm{kg}$ $4 \%$ FCM and the price of daily 4\% FCM yield were calculated for each cow. Also, economic efficiency expressed as the ratio between the price of daily 4\% FCM yield and average daily feed cost were calculated. The price of $\mathrm{kg}$ milk was 4 LE, according to prices of 2015.

\section{Statistical analysis}

The obtained results were statistically analysis of a Latin square design according to using general linear models procedure adapted by SPSS (2011) for user's guide with Latin square ANOVA. Duncan test within program SPSS was done to determine the degree of significance $(\mathrm{P}<0.05)$ among the means of treatments.

\section{$\underline{\text { Results and Discussion }}$}

\section{Chemical and calculated composition of experimental rations}

Chemical and calculated composition of different experimental rations are shown in Table 2. Rations formulated to have similar CP concentration ( $18 \%$ on average). The contents of DM, OM, CP, NFC and NFE tended to slight decrease with increasing the level of Optigen supplementation. However, the contents of $\mathrm{CF}$, ash,
NDF, ADF, hemi-cellulose and cellulose tended to increase with increasing the level of Optigen supplementation. These results may be attributed to that soybean meal decreased, while corn silage increased with increasing the level of Optigen supplementation. Lactating dairy cows requires 16$18 \% \mathrm{CP}$ on DM basis depending on milk yield and figures of fiber fractions were in accordance with those recommended by NRC (2001).

\section{Nutrients digestibility coefficients of experimental rations}

The digestibility coefficients of experimental rations are presented in Table 3. Optigen supplementation did not affect the digestibility coefficients of all nutrients. Which, the digestibility coefficients of all nutrients were nearly similar for the different experimental rations without significant differences. These results agreed with those obtained by Koster et al. (1997) who found that the substitution of rumen degradable true protein with urea does not have a negative impact on the forage intake of beef steers. Urea levels above $0.75 \%$ (99 g DM/day) depressed NDF and OM digestibility. Apparent $\mathrm{CP}$ digestion increased with increasing levels of urea and the total tract CP digestion did not differ between treatments according to Koster et al. (1997).

TABLE 2. Chemical composition (\% on DM basis) of experimental rations used in feeding dairy cows in different treatments.

\begin{tabular}{|l|c|c|c|}
\hline \multirow{2}{*}{ Items } & \multicolumn{3}{|c|}{ Treatments } \\
\cline { 2 - 4 } & G1 & G2 & G3 \\
\hline DM & 56.93 & 54.43 & 95.43 \\
\hline OM & 92.27 & 92.06 & 18.10 \\
\hline CP & 18.19 & 17.98 & 13.07 \\
\hline CF & 12.44 & 13.33 & 37.61 \\
\hline NFC & 38.10 & 37.14 & 56.32 \\
\hline NFE & 56.46 & 55.99 & 5.14 \\
\hline EE & 5.18 & 5.16 & 7.81 \\
\hline Ash & 7.73 & 7.94 & 31.34 \\
\hline Fiber fractions & & & 21.45 \\
\hline NDF & 30.80 & 31.78 & 9.89 \\
\hline ADF & 20.80 & 21.72 & 19.35 \\
\hline Hemicellulose & 10.00 & 10.06 & 2.10 \\
\hline Cellulose & 18.68 & 19.64 & \\
\hline Lignin & 2.12 & 2.08 & \\
\hline
\end{tabular}


TABLE 3. Nutrients digestibility coefficients and nutritive values of experimental rations for different treatments.

\begin{tabular}{|l|c|c|c|c|}
\hline \multirow{2}{*}{ Items } & \multicolumn{3}{|c|}{ Treatments } & \multirow{2}{*}{ SEM } \\
\cline { 2 - 5 } & G1 & G2 & \\
\hline \multicolumn{3}{|c|}{ digestibility coefficients \% } \\
\hline DM & 69.06 & 68.46 & 69.47 & 0.37 \\
\hline OM & 72.26 & 71.51 & 71.82 & 0.48 \\
\hline CP & 71.69 & 71.60 & 70.99 & 0.69 \\
\hline CF & 65.13 & 66.54 & 66.01 & 0.66 \\
\hline EE & 71.08 & 70.67 & 71.70 & 0.88 \\
\hline NFE & 79.92 & 79.95 & 79.68 & 0.63 \\
\hline NDF & 62.16 & 62.68 & 63.29 & 0.87 \\
\hline ADF & 57.52 & 57.24 & 58.69 & 0.91 \\
\hline Nutritive values & & & & 0.47 \\
\hline TDN \% & 74.55 & 74.71 & 74.64 & 0.13 \\
\hline DCP \% & 13.04 & 12.87 & 12.67 & 0.02 \\
\hline DE (Mcal/kg DM) & 3.29 & 3.29 & 3.29 & 0.02 \\
\hline ME (Mcal/kg DM) & 2.87 & 2.87 & 2.87 & 0.01 \\
\hline NE (Mcal/kg DM) & 1.72 & 1.72 & 1.72 & \\
\hline
\end{tabular}

Nutritive values of experimental rations

Nutritive values of experimental rations are presented in Table 3. The values of TDN, DCP, $\mathrm{DE}, \mathrm{ME}$ and NEL were nearly similar for the different rations and not significantly $(\mathrm{P}>0.05)$ affected by Optigen supplementation. These results cover the energy requirements of dairy cows being $1.67 \mathrm{Mcal} \mathrm{NEL} / \mathrm{kg}$ according to NRC (2001).

\section{Average daily feed intake}

Average daily feed intake by cows in different treatments are shown in Table 4. Daily average feed intake of total DM, TDN, CP, DCP, $\mathrm{DE}, \mathrm{ME}$ and NEL were nearly similar for the different experimental rations and covered the recommended requirements of the cows in this experiment as mentioned by NRC (2001). These results agreed with those obtained by Tye (2016) who found that supplementation of slow release urea did not affect intakes of DM and nutrients. It is well known that, urea can be fed to lactating dairy cows up to a concentration of $1.0 \%$ of the total ration without negative effects on DMI (Kertz, 2010).

TABLE 4. Average daily feed intake by cows in different treatments.

\begin{tabular}{|l|c|c|c|c|}
\hline \multirow{2}{*}{\multicolumn{1}{c|}{ Items }} & \multicolumn{3}{c|}{ Treatments } & \multirow{2}{*}{ SEM } \\
\cline { 2 - 5 } & G1 & G2 & G3 & \\
\hline Total feed intake as fed (kg/day) & 41.430 & 43.265 & 42.348 & \\
\hline Feed intake on DM basis: & & & & 0.01 \\
\hline Total DM (kg/day) & 23.59 & 23.55 & 23.47 & 0.11 \\
\hline TDN (kg/day) & 17.59 & 17.59 & 17.52 & 0.02 \\
\hline CP (kg/day) & 4.29 & 4.24 & 4.25 & 0.03 \\
\hline DCP (kg/day) & 3.08 & 3.03 & 2.92 & 0.49 \\
\hline DE (Mcal/day) & 77.61 & 78.77 & 77.21 & 0.50 \\
\hline ME (Mcal/day) & 67.70 & 67.59 & 67.36 & 0.27 \\
\hline NE $($ Mcal/day) & 40.57 & 41.05 & 40.37 & \\
\hline
\end{tabular}




\section{Milk yield}

The yield of actual milk and $4 \%$ fat corrected milk (FCM) for cows fed the different rations are presented in Table (5). Average daily yield of actual milk and 4\% FCM were not affected significantly $(\mathrm{P}>0.05)$ by Optigen supplementation. Average daily yield of actual milk for cows in G1, G2 and G3 were $32.48,30.40$ and $31.45 \mathrm{~kg}$, respectively. The corresponding average daily 4\% FCM yield for cows in G1, G2 and G3 were 29.67, 27.70 and $28.48 \mathrm{~kg}$, respectively. This is mainly due to the cows in all groups received their recommended nutrients allowances (NRC 2001) and because at about that level the cows were produced as much as they were capable of. These results agreed with those obtained by Tedeschi et al. (2002) who fed a polymer-coated slow release urea (Optigen 1200) and found there was no drop in daily milk yield for cows fed slow release urea. Santos and Huber (2008) reported that milk yield was unaffected when soybean meal was partially replaced by Optigen. Slow release urea supplementation not affected milk production (Tye, 2016). Golombeski et al. (2006) compared two diets containing nitrogen sources either as slow release urea diet or no slow urea diet, which partially replaced soya bean meal and reported that dietary treatment had no effect on energy corrected milk. Xin et al. (2010) found no effect of dietary polymer coated urea and soya bean meal on energy corrected milk yield.

TABLE 5. Average daily milk yield and composition for different treatments.

\begin{tabular}{|c|c|c|c|c|}
\hline \multirow{2}{*}{ Items } & \multicolumn{3}{|c|}{ Treatments } & \multirow[t]{2}{*}{ SEM } \\
\hline & G1 & G2 & G3 & \\
\hline \multicolumn{5}{|c|}{ Milk yield (kg/day): } \\
\hline Actual milk yield & 32.48 & 30.40 & 31.45 & 1.00 \\
\hline 4\% FCM yield & 29.67 & 27.70 & 28.48 & 0.93 \\
\hline \multicolumn{5}{|c|}{ Milk composition \%: } \\
\hline Fat & 3.44 & 3.40 & 3.37 & 0.05 \\
\hline Protein & 2.97 & 3.02 & 3.01 & 0.02 \\
\hline Lactose & 4.54 & 4.48 & 4.53 & 0.02 \\
\hline SNF & 8.21 & 8.22 & 8.25 & 0.04 \\
\hline TS & 11.65 & 11.62 & 11.63 & 0.08 \\
\hline Ash & 0.70 & 0.71 & 0.71 & 0.002 \\
\hline
\end{tabular}

\section{Milk composition}

Results in Table 5 revealed that the contents of fat protein, lactose, solids not fat (SNF), total solids (TS) and ash were nearly similar for the different groups and not significantly $(\mathrm{P}>0.05)$ affected by Optigen supplementation. These results reflect similar trends to milk yield. This may be due that all experimental cows were fed rations contained nearly similar nutrients contents and consumed nearly comparable quantity as shown in Tables 2 and 4. These results agreed with those obtained by Xin et al. (2010) who found no effect of dietary coated urea and soya bean meal on milk composition. Golombeski et al. (2006) compared two diets containing nitrogen sources either as slow release urea diet or no slow urea diet, which partially replaced soya bean meal SBM. Dietary treatment had no effect on milk fat and protein. Tedeschi et al. (2002) fed a polymer-coated slow release urea (Optigen 1200) and found that the addition of slow release urea had no overall impact on milk component composition. Casper and Schingoethe (1986) suggested that diets high in N might benefit from addition of a highly fermentable carbohydrate source. In response, this study was designed to evaluate the interaction of slow-release urea (SRU) and fermentable sugars (FS) on milk composition of lactating dairy cows. Inostroza et al. (2010) carried out an experiment to determine the influence of Optigen as a source of NPN had no effect on milk composition.

\section{Urea and urea-N concentrations in milk}

The concentrations of urea and urea-N in milk for the different groups are presented in Table 6. Optigen supplementation did not significantly $(\mathrm{P}>0.05)$ affect urea and urea- $\mathrm{N}$ concentrations in milk. This may be due that all experimental cows 
were consumed nearly similar quantities of $\mathrm{CP}$ and DCP as shown in Table 4. The urea concentration in milk in cattle are influenced by the amount of crude protein in the diet (Carlsson \& Bergstrom, 1994, Gonda \& Lindberg, 1994 and Baker et al., 1995), as well as by degradable intake protein (DIP) and undegradable intake protein (UIP) (Ropstad et al., 1989). Erbersdobler and Zucker (1980) and Oltner and Wiktorsson (1983) have postulated that a surplus of $\mathrm{N}$ intake increases blood urea nitrogen (BUN) which has a close relationship with milk urea nitrogen, MUN (Eckart, 1980, Oltner and Wiktorsson, 1983 and Dhali, 2001), because urea freely diffuses from blood to milk (Gustafsson and Palmquist, 1993). Golombeski et al. (2006) compared two diets containing nitrogen sources either as slow release urea diet or no slow urea diet, which partially replaced soya bean meal SBM. Dietary treatment had no effect on milk urea nitrogen MUN.

TABLE 6. Urea and urea-N concentrations in milk and urea-N and total protein concentrations in blood plasma.

\begin{tabular}{|c|c|c|c|c|}
\hline Period & G1 & G2 & G3 & SEM \\
\hline \multicolumn{5}{|l|}{ Milk: } \\
\hline $\begin{array}{l}\text { Urea } \\
(\mathrm{mg} / 100 \mathrm{ml})\end{array}$ & 31.33 & 35.21 & 31.28 & 1.38 \\
\hline $\begin{array}{l}\text { Urea-N } \\
(\mathrm{mg} / 100 \mathrm{ml})\end{array}$ & 14.52 & 16.46 & 15.11 & 0.58 \\
\hline \multicolumn{5}{|l|}{ Blood plasma: } \\
\hline $\begin{array}{l}\text { Urea-N } \\
(\mathrm{mg} / 100 \mathrm{ml})\end{array}$ & 18.88 & 18.10 & 18.22 & 0.90 \\
\hline $\begin{array}{l}\text { Total protein } \\
(\mathrm{g} / 100 \mathrm{ml})\end{array}$ & 8.25 & 8.15 & 8.04 & 0.21 \\
\hline
\end{tabular}

Urea- $N$ and total protein concentrations in blood plasma

Urea-N and total protein concentrations of in blood plasma for the different groups are presented in Table 6. Optigen supplementation did not significantly $(\mathrm{P}>0.05)$ affect urea-N and total protein concentrations in blood plasma. This mainly due that the CP and DCP intakes were nearly comparable in all tested rations (Table 4). The urea concentration in plasma in cattle are influenced by the amount of crude protein in the diet (Carlsson \& Bergstrom, 1994, Gonda \& Lindberg, 1994 and Baker et al., 1995), as well as by degradable intake protein (DIP) and undegradable intake protein (UIP) (Ropstad et al., 1989). Wahrmund et al. (2007) fed beef cows no supplement, urea, or Optigen ${ }^{\circledR}$ while having ad libitum access to bahia grass and reported no differences in blood urea nitrogen. Kononoff et al. (2006) fed high forage diets containing Optigen $\AA$ and also reported no change in plasma urea nitrogen in dairy heifers compared to heifers consuming a supplement containing soybean meal.

\section{Feed conversion ratio}

Feed conversion ratio by dairy cows in different groups are shown in Table 7. The amounts of DM, TDN, DCP, DE, ME and NEL required for produce one $\mathrm{kg} \mathrm{4 \%} \mathrm{FCM} \mathrm{did} \mathrm{not} \mathrm{show} \mathrm{any}$ significant $(\mathrm{P}>0.05)$ differences among the tested rations contained the different levels of Optigen. This may be due that all experimental cows were fed rations contained nearly similar nutrients contents and have comparative nutritive values as shown in Tables (2 and 3). Optigen $® I I$ improved the feed efficiency when compared to urea on high concentrate diets but reduced feed efficiency on high forage diets (Holder, 2012). Tedeschi et al. (2002) fed a polymer-coated slow release urea (Optigen 1200) and found an improvement in feed efficiency.

TABLE 7. Feed conversion ratio by dairy cows fed experimental rations.

\begin{tabular}{|l|c|c|c|c|}
\hline Items & R1 & R2 & R3 & SEM \\
\hline $\mathrm{DM}(\mathrm{kg} / \mathrm{kg} 4 \%$ FCM $)$ & 0.80 & 0.85 & 0.83 & 0.03 \\
\hline $\mathrm{TDN}(\mathrm{kg} / \mathrm{kg} 4 \% \mathrm{FCM})$ & 0.59 & 0.65 & 0.62 & 0.02 \\
\hline $\mathrm{CP}(\mathrm{kg} / \mathrm{kg} \mathrm{4 \%} \mathrm{FCM})$ & 0.14 & 0.15 & 0.15 & 0.006 \\
\hline $\mathrm{DCP}(\mathrm{kg} / \mathrm{kg} 4 \% \mathrm{FCM})$ & 0.10 & 0.11 & 0.10 & 0.004 \\
\hline $\mathrm{DE}(\mathrm{Mcal} / \mathrm{kg} 4 \% \mathrm{FCM})$ & 2.61 & 2.85 & 2.72 & 0.10 \\
\hline $\mathrm{ME}(\mathrm{Mcal} / \mathrm{kg} 4 \% \mathrm{FCM})$ & 2.28 & 2.49 & 2.38 & 0.09 \\
\hline $\mathrm{NE}_{\mathrm{L}}(\mathrm{Mcal} / \mathrm{kg} 4 \% \mathrm{FCM})$ & 1.36 & 1.48 & 1.41 & 0.05 \\
\hline
\end{tabular}

\section{Economic efficiency}

Results of economic efficiency for different groups are shown in Table 8. Average daily feed cost was nearly the same for the different groups and not significantly $(\mathrm{P}>0.05)$ affected by Optigen supplementation. These results may be attributed to that the cost of supplemented Optigen nearly similar to the price of soybean was replaced plus the price of corn silage was added. However, feed cost per kg milk produced nearly similar being 2.06, 2.16 and $2.11 \mathrm{LE} / \mathrm{kg}$ milk for the 1st, 2nd and 3rd groups, respectively. The corresponding values of economic efficiency were 1.94, 1.85 and 1.90, respectively. Economic simulations, 
using the observed milk yield response, indicated that changes in income over feed cost were more favorable at lower energy supplement and additive prices and higher soybean meal and milk prices (Inostroza et al., 2010).

TABLE 8. Economic efficiency by dairy cows fed experimental rations.

\begin{tabular}{|c|c|c|c|c|}
\hline Items & R1 & R2 & R3 & SEM \\
\hline $\begin{array}{l}\text { Average daily } \\
\text { feed cost (LE) }\end{array}$ & 66.87 & 65.59 & 66.23 & 0.45 \\
\hline $\begin{array}{l}\text { Daily feed cost } \\
\text { (LE)/kg milk }\end{array}$ & 2.06 & 2.16 & 2.11 & 0.08 \\
\hline $\begin{array}{l}\text { Daily price of } \\
\text { milk yield (LE) }\end{array}$ & 129.92 & 121.60 & 125.80 & 3.87 \\
\hline $\begin{array}{l}\text { E c o n o m i c } \\
\text { efficiency }\end{array}$ & 1.94 & 1.85 & 1.90 & 0.06 \\
\hline
\end{tabular}

\section{Conclusions}

From these results, it could be concluded that, Optigen supplementation for lactating Holstein cows did not showed any significant effects on feed intake, digestibility, milk yield and composition along with feed conversion ratio and economic efficiency.

\section{References}

Akay, V., Tikofsky, J., Holtz, C. and Dawson, K.A. (2004) Optigen ${ }^{\circledR} 1200$ : Controlled release of nonprotein nitrogen in the rumen. In: Nutritional Biotechnology in the Feed and Food Industries. Lyons, T.P. and Jacques, K.A. (Ed.) pp. 179-185, Nottingham Univ. Press, Nottingham, UK.

AOAC (2000) "Official Methods of Analysis", 15th ed., Association of Official Analytical Chemists, Arlington, VA., USA.

Baker, L.D., Ferguson, J.D. and Chalupa, W. (1995) Responses in urea and true protein of milk to different feeding schemes for dairy cows. J. Dairy Sci., 78, 2424-2434.

Beauchemin, K.A., Colombatto, D., Morgavi, D.P., Yang, W.Z. and Rode, L.M. (2004) Mode of action of exogenous cell wall degrading enzymes for ruminants. Can. J. Anim. Sci., 84, 13-22.

Carlsson, J. and Bergstrom, J. (1994) The diurnal variation of urea in cow's milk and how milk fat content, storage and preservation affects analysis by a flow injection technique. Acta Vet. Scand., 35, 67-77.

Casper, D.P. and Schingoethe, D.J. (1986) Evaluation of urea and dried whey in diets of cows during early lactation. J. Dairy Sci., 69, 1346-1354.

Dhali, A. (2001) Studies on the effect of feeding management systems on blood and milk urea concentration in dairy cattle. Ph.D. thesis. National Dairy Research Institute (Deemed University), Karnal, India.

Dos Santos, J.F., Pereira, M.N., Dias, G.S., Jr., L.L., Bitencourt, N.M. Lopes, S. Siécola, Jr. and Silva, J.R.M. (2008) Response of lactating cows to partial replacement of soybean meal by Optigen ${ }^{\circledR}$ II or urea. J. Anim. Sci., 86 (E-Suppl. 2):490. (Abstract)

Eckart, K. (1980) A a contribution to monitor the protein and energy supply to cows. Ph.D. Thesis, Technical University, Munich, Germany

Erbersdobler, H. and Zucker, H. (1980) Harnstoff der Milch-ein Indikator der Proteinversorgung von Milchkuhen [Urea in milk- an indicator for protein supply of dairy cows]. Kraftfuter, 63 (1),10.

Gaines, W.L. (1928) The energy basis of measuring milk yield in dairy cows. Tech. Bull. No. 308 . Agric. Exp. Sta., Champaign, IL.

Galo, E., Emanuele S., Sniffen C., White J. and Knapp J. (2003) Effects of a polymer-coated urea product on nitrogen metabolism in lactating Holstein dairy cattle. J. Dairy Sci., 86, 2154-2162.

García-González, R., Tricarico, J.M., Harrison, G.A., Meyer, M.D., McLead, K.M., Harmon, D.L. and Dawson, K.A. (2007) Optigen ${ }^{\circledR}$ II is a sustained release source of non-protein nitrogen in the rumen. J. Anim. Sci., 85 (E-Supp. 1):98 (Abstract).

Golombeski, G.L., Kalscheur, K.F., Hippen, A.R. and Schingoethe, D.J. (2006) Slow-Release Urea and Highly Fermentable Sugars in Diets Fed to Lactating Dairy Cows. J. dairy. Sci., 89, 4395-4403.

Gonda, H.L. and Lindberg J.E. (1994) Evaluation of Dietary Nitrogen Utilization in Dairy Cows Based on Urea Concentrations in Blood, Urine and Milk, and on Urinary Concentration of Purine Derivatives. Acta Agriculturae Scandinavica, Section A-Animal Science, 44, 236-245. 
Gustafsson, A.H. and Palmquist D.L. (1993) Diurnal variation of rumen ammonia, serum urea, and milk urea in dairy cows at high and low yields. J. Dairy Sci., 76, 475-484.

Hall, M.B. (2003) Challenges with nonfiber carbohydrate methods. J. Anim. Sci., 81 (12), 3226-32.

Harrison, G.A. and Karnezos, T.P. (2005) Can we improve the efficiency of nitrogen utilization in the lactating dairy cow? In: Recent Advances in Animal Nutrition in Australia. School of Rural Science and Agriculture, University of New England, 15, 146154.

Holder, V.B. (2012) The effects of slow release urea on nitrogen metabolism in cattle. Ph D Diss., Univ. of Kentucky, Lexington

Inostroza, J.F., Shaver, R.D., Cabrera, V.E. and Tricaricot, J.M. (2010) Effect of diets containing a controlled-released urea product on milk yield, milk composition, and milk component yields in commercial Wisconsin dairy herds and economic implications. The Professional Animal Scientist, 26, 175-180.

ICF Consulting (2004) Potential concentrations of Optigen residues in the environment and a comparison to similar residues from other sources. Technical report, Alltech Inc., Catnip Hill Pike, Nicholasville, KY.

Kertz, A.F. (2010) Review: Urea Feeding to Dairy Cattle: A Historical Perspective and Review. The Professional Animal Scientist, 26, 257-272

Kononoff, P.J., Heinrichs, A.J. and Gabler, M.T. (2006) The effects of nitrogen and forage source on feed efficiency and structural growth of pre-pubertal Holstein heifers. The Professional Animal Science, 22, 84-88

Koster, H.H., Cochran, R.C., Titgemeyer, E.C., Vanzant, E.S., Nagaraja, T.G. Kreikemeier, K.K. and Jean, G.S. (1997) Effect of increasing proportion of supplemental nitrogen from urea on intake and utilization of low-quality, tallgrass-prairie forage by beef steers. J. Anim. Sci., 75, 1393-1399

Krehbiel, C.R., Bandyk, C.A., Hersom, M.J. and Branine, M.E. (2007) Alpharma Beef Cattle Nutrition symposium: Manipulation of nutrient synchrony. J. Anim. Sci., 86, E285-E286
Murillo, M., Alvarez, E.G., Cruz, J., Castro, H., Sánchez, J.F., Vázquez, M.S. and Zinn, R.A. (2000) Interaction of forage level and fibrolytic enzymes on digestive function in cattle. Proc. West. Sec. Am. Soc. Anim. Sci., 51, 324-327

NRC (2001) Nutrient Requirements of Dairy Cattle: Seventh Revised Edition. The National Academies Press.

Oltner, R. and Wiktorsso, H. (1983) Urea concentration in milk and blood as influenced by feeding varying amounts of protein and energy to dairy cows. Livest. Prod. Sci., 10, 457-467.

Ropstad, E., Vik-Mo, L. and Refsdal A.O. (1989) Levels of milk urea, plasma constituents and rumen liquid ammonia in relation to the feeding of dairy cows during early lactation. Acta Vet. Sacnd., 39, 199-208.

Santos, F.P. and Huber, J.T. (2008) Quality of bypass protein fed to high-producing cow is important. Feedstuffs, 79 (38), 12-15

Schneider, B.H. and Flatt, W.P. (1975) The evaluation of feeding through digestibility experiments. Univ. Georgia Press, Athens, 169p.

SPSS (2011) Statistical package for the social sciences, Release 19, SPSS INC, Chicago, USA

Tedeschi, L.O., Baker, M.J., Ketchen, D.J. and Fox, D.G. (2002) Performance of growing and finishing cattle supplemented with a slow-release urea product and urea. Can. J. Anim. Sci., 82, 567-573

Tye, M. (2016) Effects of feeding high-moisture corn grain with slow-release urea in dairy diets on lactational performance, energy and nitrogen utilization, and ruminal fermentation profiles by lactating cows. M.Sci. Animal, Dairy, and Veterinary Sciences, Utah State Univ.

Van Keulen, J.V. and Young B.A. (1977) Evaluation of acid insoluble ash as a natural marker in ruminant digestibility studies. J. Animal. Sci. 44, 282-287

Van Soest, P.J. (1963) Use of detergents in the analysis of fibrous feeds. II- A rapid method for the determination of fiber and lignin. $A O A C, \mathbf{4 6}, 830$

Van Soest, P.J. and Marcus. W.C. (1964) A method for the determination of cell wall constituents in forages

J. Sus. Agri. Sci. Vol. 43, No.1 (2017) 
using detergents and the relationship between this fraction and voluntary intake and digestibility. $J$. Dairy Sci., 47, 704.

Wahrmund, J., de Araujo. D.V., Hersom. M. and Arthington. J. (2007). Evaluation of Optigen II as a source of rumen degradable protein for mature beef cows. Technical report, Florida beef report, Florida, USA.

Weiss, B. (2015) Optimizing and evaluating dry matter intake of dairy cows. WCDS Advances in Dairy Technology, 27, 189-200.
Xin, H., Schaefer, D., Liu, Q., Axe, D. and Meng, Q. (2010) Effects of polyurethane coated urea supplement on in vitro ruminal fermentation, ammonia release dynamics and lactating performance of Holstein dairy cows fed a steamflaked corn-based diet. Asian-Aust. J. Anim. Sci., 23, 491-500.

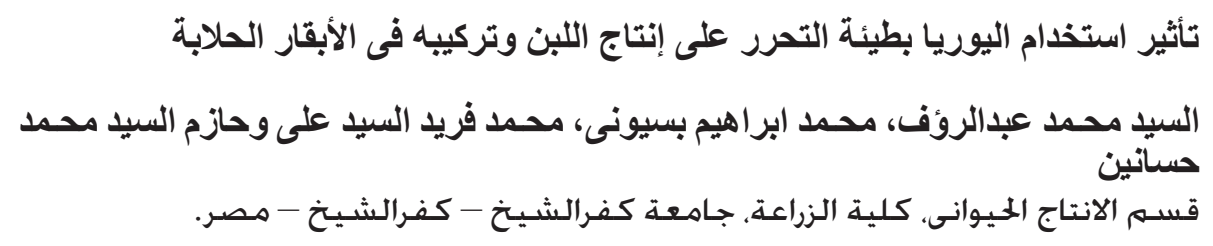

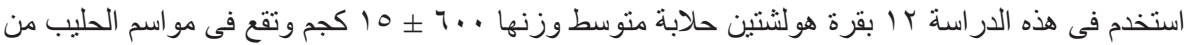

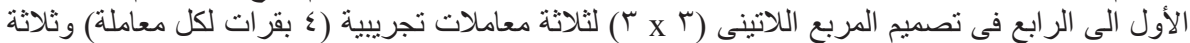

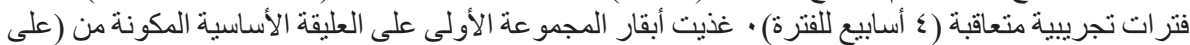

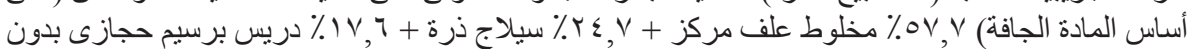

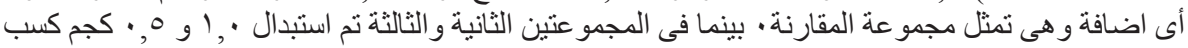

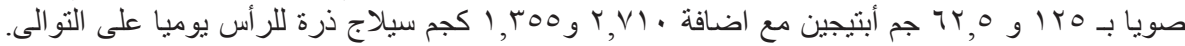

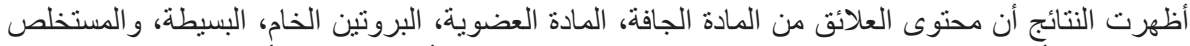

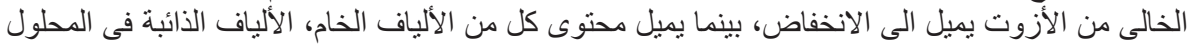

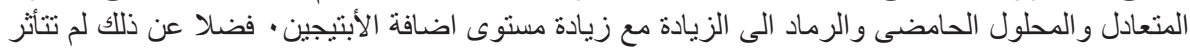

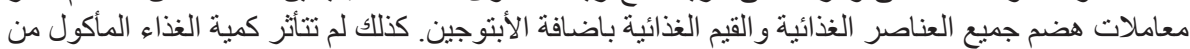

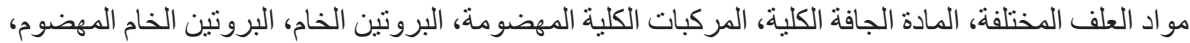

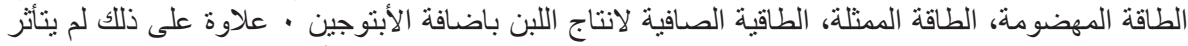

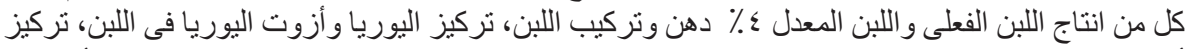

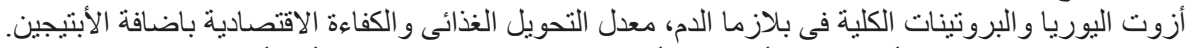

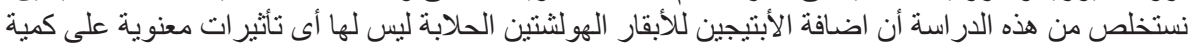

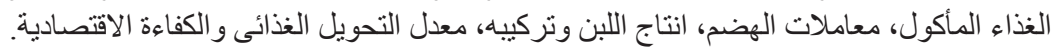

